\title{
A Systematic Mapping Study on Business Process VARIABILITY
}

\author{
George Valença ${ }^{1,}$ Carina Alves ${ }^{1}$, Vander Alves ${ }^{2}, \mathrm{Nan}_{\mathrm{Niu}}{ }^{3}$ \\ ${ }^{1}$ Informatis Center, Federal University of Pernambuco (UFPE), Recife, Brazil \\ \{gavs, cfa\} ecin.ufpe.br \\ ${ }^{2}$ Computer Science Department, University of Brasılia (UnB), \\ Brasília, Brazil \\ valves@cic.unb.br \\ ${ }^{3}$ Department of Computer Science and Engineering, Mississippi State University, \\ MS, USA \\ niu@cse.msstate.edu
}

\begin{abstract}
Business Process Management aligns organisational strategy and business operation. The dynamic environment within which organisations operate promotes changes in business processes, in a phenomenon known as business process variability. The goal of this research is reviewing business process variability literature to comprehend this phenomenon and analyse its theoretical foundation. Through a systematic mapping study, 80 primary studies acted as sources of evidence to answer three research questions. By summarizing this theoretical background, we establish a conceptual synthesis of business process variability. We equally describe business process variability approaches and observe whether these were empirically assessed. Finally, we discuss research opportunities in the field. Our study shows that concepts in business process variability domain are used in an inconsistent manner, demanding a common vocabulary. A significant number of approaches is available, but most of them lack empirical studies. Additionally, our findings provide a diagnosis of the major challenges in the field.
\end{abstract}

\section{KEYWORDS}

Business Process Management, Business Process Modelling, Business Process Variability, Systematic Mapping Study.

\section{INTRODUCTION}

Business processes have improved management activities, approximating the strategic planning from those who execute their work to achieve organisational goals. They are the main instruments to organise activities and improve the understanding of their interrelationships [1]. After introducing Business Process Management (BPM) practices, the organisation benefits from a continuous alignment between the strategy and the implementation. This disciplined approach is governed by a lifecycle which models, implements, monitors and improves business processes to reach the results desired by the institution [2].

Business processes need to be adapted as a response to evolutions in internal and external environment. In this scenario, changes in business domain, new technologies or industry standards, compliance with government regulations and stakeholders' needs are examples of change inductors [3][4][5][6][7]. The consequence of this dynamic context is typically referred to 
as business process variability [6], which is an emergent field in BPM with many of its proposals inspired by theories from Software Product Line (SPL) to handle process variability [8][9][10][11][12][13][14][15][16][17].

Variability in business processes is necessary in order to organisations deal with environmental changes. However, this situation introduces challenges on both technical and business levels, and it demands enterprises to quickly adapt their processes and respective supporting systems. Managing process variability is a non-trivial task as it requires specific standards, methods and technologies to support process variability. These techniques increase companies' competitiveness while enabling them to keep the alignment between processes and strategies.

The work of Soffer [6], published in 2004, represents one of the first contributions to investigate the scope of changes in business processes. Since then, a wide range of efforts has been spent on treating the variability phenomenon. However, there has been no effort to generate a detailed analysis of the literature in this field. Hence, we decided to investigate business process variability through a systematic mapping study, which is a method that enables a precise review of a broader research topic [18][19]. This analysis aimed to clarify business process variability and provide a detailed description of its main concepts. The central problems investigated by this study are: how does business process variability work and what is the available support to manage it? This statement was mapped into three research questions to define the main characteristics of business process variability, examine the technical support provided by BPM literature and identify open issues in the field. Our goal is to provide relevant information about business process variability, and allow companies and researchers to better interpret this issue.

In SPL field, variability management is addressed through modelling and execution perspectives. Features can be statically or dynamically bound [31]. This separation is also considered in business process variability approaches, with design time or runtime-oriented focuses. These are different and independent paradigms: design-time approaches treat variations during process definition while run-time techniques propose variability facilities during process execution. Given that, we decided to initially explore studies on design-time process variability.

The results of our study revealed that concepts within the business process variability field are used in a quite inconsistent and vague form. Considering that this problem impacts the communication among academics and limits the understanding of general readers, we defined a comprehensive synthesis of business process variability notions. We also identified a significant number of approaches for process variability management. Part of these methods is supported by automated tools, although only a small percentage had been empirically assessed. In addition, most studies employed case studies as evaluation strategy. We also discussed the main open issues in business process variability literature, which are centred on topics such as: automatic verifying the soundness of business process variants, graphically representing additional dimensions of variability in process models, introducing configuration facilities in reference process models, providing decision-making support for analysts during process configuration and introducing business process flexibility requirements in BPM tools.

The remainder of the paper is organised as follows. Section 2 briefly describes the methodology employed by the systematic mapping study. Section 3 presents the results, while Section 4 discusses our findings. Section 5 describes threats to validity. Finally, Section 6 provides final remarks and future works. 


\section{Systematic Mapping Study Protocol}

This research aimed to analyse studies in business process variability by executing a secondary research known as systematic mapping study. According to Kitchenham et al. [19], this type of study examines a broader topic and classifies the literature in that specific domain, using high level research questions. Mapping studies main benefit is to provide research community with baselines for further research activities while delivering value to practitioners with an overview of a specific area. A fundamental characteristic of this type of research is basing its execution on a protocol, states Budgen et al. [18]. Our mapping study protocol was based on guidelines provided by Kitchenham et al. [20], Budgen et al. [18], and Petersen et al. [21] and on good practices from studies conducted by Kitchenham [22][19].

\subsection{Research Questions}

Our overall goal is to investigate how business process variability works and what is the support provided by literature. To address this objective, the following research questions were defined.

\section{RQ1. What are the characteristics of business process variability?}

The first research question (RQ1) aims at offering a theoretical understanding of business process variability phenomenon. By describing business process variability and the notions it encompasses we aim to support the definition of a common language to improve communication among researchers and practitioners.

\section{RQ2. What are the available approaches for business process variability management?}

This research question evaluates the theoretical and practical support offered for practitioners to deal with business process variability. It is dismembered in three sub-questions:

\section{RQ2.1. What are the characteristics of the approaches?}

This sub-question strives to describe the approaches for treating business process variability. Additionally, the classification of the proposals according to their main focus helps practitioners to assess the available support [33] concerning a particular variability approach.

\section{RQ2.2. Is automated tool support available?}

The aim of this sub-question is to investigate the availability of automated tool support provided by the variability approaches. It lists applications which are freely offered and also those presented as proprietary tools or as plug-ins for proprietary BPM suites. This may support organisations to evaluate technologies [34] for business process variability management.

\section{RQ2.3. How are the approaches empirically evaluated?}

This sub-question's goal is revealing the percentage of studies that were empirically assessed. Highlighting proposals with an empirical evaluation and the methods used in their assessment can play an important role in transferring research outcomes into practice. 


\section{RQ3. What are the current challenges within business process variability field?}

The goal of RQ3 is to explore the current challenges in business process variability topic. It strives to describe research opportunities regarding variability management and invite research community to address them. It complements the overview of the state-of-the-art in RQ2.

\subsection{Search Process}

As proposed by Kitchenham [20], searches for primary studies generally start employing electronic databases. To improve the quality of search results, we have also manually analysed the main venues for BPM researchers to publish their results. These acted as additional sources of evidence. Both automatic and manual searches were not restricted by publication year. The search process is presented in Figure 1, being described as follows.

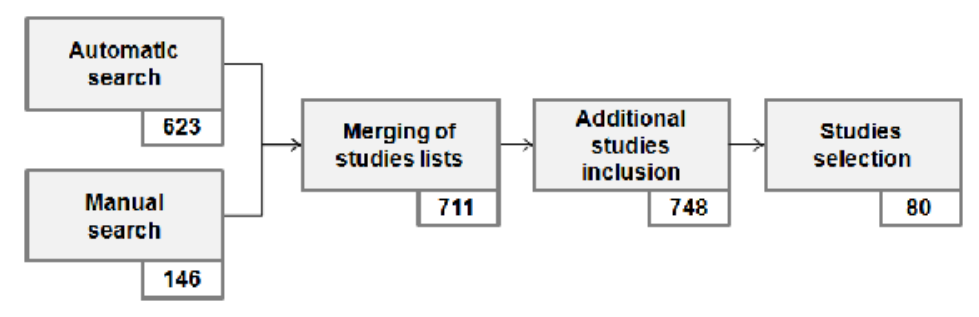

Figure 1. Search process

\section{Step 1 - Automatic Search}

During this step, we searched the following databases: ACM, Wiley InterScience, SpringerLink, ScienceDirect, CiteSeerX and IEEEXplore. The search string used in this procedure was composed of two parts: process AND variability. To improve this initial structure, we determined synonyms, related or complementary terms and alternative spellings. These additional keywords were incorporated using OR and provided a more complete query. We have tested the new search string through a sanity-check, introducing the expression in part of the databases to assure its structure worked as expected. The final search string is presented below.

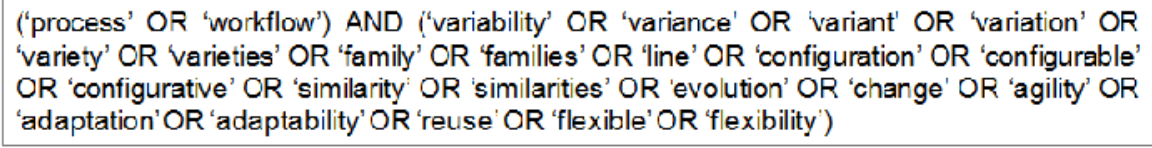

The automatic search returned 13.619 papers, with the following division: $30 \%$ obtained from ScienceDirect, $23.3 \%$ from IEEE, $16.2 \%$ from Wiley InterScience, $11 \%$ from Springer, $10.4 \%$ from ACM and $9.1 \%$ from CiteSeer. An initial manual filtering was then executed to refine the results. The criteria applied in this procedure considered paper's type, title and venue in which it was published. First, the type of the reference was verified: only papers published on conferences, journals or workshops had their titles evaluated. Next, since this review only included studies investigating business process variability in BPM or Information Technology fields, we considered important to analyse the source where each study was published. Hence, papers belonging to out of scope venues (e.g. "Climate Dynamics") were discarded. As a result of this procedure, $6.8 \%$ (928) of the papers were retained. Since in the resultant list we found papers from different venues reporting the same study, an initial application of the second inclusion criterion (see Section 2.3) was necessary. Accordingly, 623 studies were retained. 


\section{Step 2 - Manual search}

We established a list of 13 journals and 6 conferences for the manual search, over which the manual search was performed (Table 1). This procedure retrieved 146 papers, which had as main sources: Int'l Conference on BPM (37.7\%), Int'l Conference on Advanced Information Systems Engineering (25\%), Int'l Conference on Conceptual Modeling (5.5\%), Data and Knowledge Engineering (4.8\%) and Int'l Journal of Cooperative Information Systems (4.8\%).

\section{Step 3 - Merging of studies lists}

This step aimed at merging the automatic and manual search results and discard duplicate papers.

We aggregated 623 papers from the automatic search and 146 from the manual search, with a resultant list of 711 papers (the absence of 58 items was due to overlaps in input lists).

Table 1. Searched journals and conferences.

\begin{tabular}{|l|l|}
\hline Type & \multicolumn{1}{|c|}{ Venue } \\
\hline J & Business Process Management Journal \\
\hline J & Communications of the ACM \\
\hline J & Data and Knowledge Engineering \\
\hline J & IEEE Software \\
\hline J & IEEE Transactions on Knowledge and Data Engineering \\
\hline J & IEEE Transactions on Software Engineering \\
\hline J & IEICE Transactions on Information and Systems \\
\hline J & Information and Software Technology \\
\hline J & Information Systems and e-Business Management \\
\hline C & Int'l Conference on Advanced Information Systems Engineering \\
\hline C & Int'l Conference on BPM \\
\hline C & Int'l Conference on Conceptual Modeling \\
\hline C & Int'l Conference on Software Engineering (ICSE) \\
\hline J & Int'l Journal of Cooperative Information Systems \\
\hline J & Int'l Requirements Engineering Conference (RE) \\
\hline J & Int'l Software Product Line Conference (SPLC) \\
\hline J & Journal of Systems and Software \\
\hline J & Requirements Engineering Journal \\
\hline J & Software and System Modeling \\
\hline & \\
\hline
\end{tabular}

\section{Step 4 - Additional studies inclusion}

The goal of this step was to include papers that were not mapped by search databases or which were not identified during manual searches (e.g. $\mathrm{PhD}$ and master theses addressing business process variability). Therefore, we included 37 additional works identified on references of process variability papers obtained in steps 1 and 2 . A fourth list with 748 papers was generated.

\section{Step 5 - Studies selection}

During this step, we applied inclusion and exclusion criteria based on the abstract, introduction and conclusion of each paper. From the 748 papers, 127 were retained for further analysis. To retain studies exploring design-time process variability and discard those exclusively focused on 
the runtime environment, we applied a filter on the abstract, introduction and conclusion of the papers to analyse their scope. We also consulted some authors to confirm our findings and discuss this separation. Accordingly, we obtained 80 primary studies. The complete list of selected papers is described in Appendix A.

\subsection{Selection Criteria}

The criteria list aims at supporting the selection of the primary studies to be analysed in the mapping study. We present below the set of criteria applied.

Inclusion Criteria - (1) The study approaches the variability issue and/or one of the topics in the search string; (2) Where several papers reported the same study, only the most complete one should be included; (3) Where several studies were reported in the same paper, each relevant study was treated separately; (4) Studies that answer at least one research question.

Exclusion Criteria - (1) Studies that are not written in English; (2) The paper is outside the business processes field; (3) Whitepapers, books, posters, summaries of articles, tutorials, panels, presentations, personal opinion pieces and/or viewpoints were excluded; (4) Any study not accessible or not available in PDF or Microsoft Word format.

\subsection{Data Extraction and Analysis}

After the search and selection procedures, the primary studies were examined through an extraction form. The papers were analysed considering the information required by each research question. The extraction spreadsheet was filled with text excerpts from the primary studies to answer each question. We have extracted the following data from each study: (1) Source, title, authors and year of publication; (2) Business process variability definition, related ideas and relationships; (3) Name and brief description of the proposed approach; (4) Availability of a software tool. In case there exists tool support, we further identify whether the tool is opensource or proprietary; (5) Empirical methods employed to evaluate the approach; (6) Open issues within business process variability topic.

Individual textual files were generated to assemble the information regarding each research question. To analyse data, an open coding procedure was conducted [16]. This strategy has the purpose of generating categories through the division of data gathered, yielding several concepts. These definitions can then be modified, given comparisons and merges of notions.

\section{RESULTS}

\subsection{Overview of Studies}

No time restrictions were defined for the papers to be gathered by the search process. However, the final list of papers was limited to the past decade, with studies from 2004 until 2011. The investigation of business process variability was in continuous rise from 2004 to 2008. In the last 3 years the number of studies published in this topic experienced a slight decrease.

Concerning the source, among the 80 primary studies, $37.5 \%$ were published in conference proceedings, $30 \%$ were originated from workshops, $20 \%$ were published in journals, $8.75 \%$ were technical reports and $3.75 \%$ were academic theses. The predominance of conference papers and the large number of workshop studies suggest that research on business process variability is at an initial stage. In addition, the 80 primary studies were associated to 142 different authors. Among 
these, it was possible to identify that Marcello la Rosa, Marlon Dumas, Selmin Nurcan and Wil M.P. van der Aalst were the top contributors to business process variability field.

\subsection{Evaluation of Research Questions}

We discuss in this section the results from the assessment of the primary studies, which were obtained by applying the protocol detailed in Section 2. This analysis considered the information required by each research question.

\subsubsection{RQ1: What are the characteristics of business process variability?}

This research question aimed to explore business process variability as a concept and provide a clear definition of this phenomenon. Passages from the primary studies that provide a theoretical background on business process variability were integrated and evaluated in an open coding procedure. Theme categories represented the available knowledge with respect to business process variability and summarised concepts and theories within this topic. Drawing these conclusions, we may direct efforts of BPM researchers towards a more conscious and coordinated use of conceptual knowledge.

Business process variability is the capability of an artefact to be configured, customised or changed for use in a specific domain. Given its conceptual foundation on reuse-oriented development in BPM, it enables the reuse of parts of a model while adaptations to its functioning are introduced. Many authors use the term flexibility to refer to the notion of variability in the scope of business processes. Similar to business process variability, business process flexibility is the ability of a process to adapt to the changes in the environment or to its changing requirements. It concerns how rapid and easy a process model is modified.

Several authors split business process variability in two perspectives: design-time and runtime. The former type essentially refers to variations of models during modelling phase, before they are implemented in a workflow management system or BPMS for execution. The latter type is associated with processes on execution, addressing runtime variability with exception handling approaches. These types are complementary to each other and can also be called design-time and runtime business process flexibility, given the tiny boundary between variability and flexibility notions.

A reference business process model supports the reuse paradigm by collecting and depicting proven best practices of a specific domain. It provides a starting point to define process models for a particular setting (e.g. a company) and improves modelling by avoiding the construction of a model from scratch. However, the common traits captured by these models do not turn them into plug and play solutions. Adjustments must be executed, since these generally do not offer configuration facilities.

The concept of configurable business process model implements the notion of reference business process models. It is a step forward towards the reuse of business processes. They are defined via a configurable process modelling language or notation, which provides means to insert variability in a process model. Configurable models are constructed by merging several business process variants, which are processes achieving the same goals but slightly differing from each other in their structure due to domain specific requirements. Variants are versions of a particular process model called business process type, which is defined at design-time and represents a standard way of acting within an organization. Variability is achieved by introducing placeholders in a configurable model referred to as variation points, also known as configurable 
nodes or adjustment points. Options are assigned to them by means of variability mechanisms, which are techniques (e.g. extension) that realise variability in a model.

To customise configurable models to a specific solution, an analyst selects the most suitable option for each variation point, in a procedure called business process configuration. It derives a process from a configurable model by restricting its behaviour and can be regarded to as designtime business process variability. The scheme spawned via a configurable model is a process variant, which is enacted as a business process instance at runtime. If changes are implemented during the execution of this process instance, this is referred to as runtime business process variability.

Process configuration implies decision making and it is therefore guided by configuration decisions. These judgements are applied over each variation point to assess its available choices, based on information from the context in which the derived model should be employed. This information may be expressed as configuration requirements (hard constraints) and configuration guidelines (recommendations), which can be bound to variation points to restrict the combination of available options.

Configuration requirements and guidelines aim to avoid undesirable configurations. This leads to the notion of business process correctness, which is a characteristic of the generated process models being valid in a syntactic and/or semantic form. The syntactic property is centred on the adequate use of the modelling notation through which the model structure was created. The semantic property is also called business process soundness, analysing the dynamic behaviour of the process model to ensure that no deadlocks or livelocks in the control-flow prevent a proper completion.

The collection of variants obtained by means of process configuration can be denoted as business process line. These models represent alternative forms of the same underlying process and share an invariant nucleus known as core process. This common structure expresses the compromises kept by members of a process line. In addition, the degree of commonality a process model keeps with respect to another model within a process line is known as business process similarity. It results from the comparison of multiple aspects of process variants to describe to which degree they share a similar structure.

\subsubsection{RQ2: What are the available approaches for business process variability management?}

The results of this research question provide an overview of the proposed solutions to handle business process variability. We identified a set of approaches and supporting tools in the selected studies, which are classified and briefly described below. Additionally, we analysed the empirical evaluations conducted by business process variability studies in order to assess the rigour and feasibility of the proposed approaches.

\section{RQ2.1: What are the characteristics of the approaches?}

Fifty-seven (71\%) among the 80 primary studies developed an approach for business process variability management. Less than a third of the selected studies (23) did not provide a specific approach. These studies proposed surveys (e.g. survey of flexibility requirements (P6)) or general evaluations (e.g. assessment of techniques for evaluating process similarity (P9)), investigations (e.g. analysis of process change scope (P11)) and formal discussions (e.g. Weick's theory (P13)). However, it is relevant to remark that studies proposing novel approaches also brought a background concerning theories behind the practical perspective. 
This review identified 57 unique approaches to deal with business process variability from different aspects (e.g. process configuration, process flexibility, etc.). Although the studies addressed different issues, they rarely gave the same emphasis to these perspectives. Hence, to conduct a better analysis, the approaches were classified considering their main focus (in bold), which follows the aspects of business process variability presented in former section

A set of approaches investigated business process configuration procedure, which aims to obtain a variant from a process reference model or configurable process model. To support this activity, some studies also explored domain aspects and decision-making aspects. We included the following 10 studies (around 18\%) in this category: P19, P26, P27, P34, P36, P39, P45, P47, P50 and P61. These works analysed how to assist the individualization of a process model to a particular context. In order to enhance this activity, the use of non-functional requirements was proposed as constraints that the process must comply with during instantiation (P27). It was also found a decision support model in the form of a questionnaire-driven approach independent of process modelling notation (P68). Another study proposed a description of change patterns to be applied during model customization (P19). The use of views by means of queries (P61) and the control of context factors through the use of decision tables (P39) were also examples of solutions proposed in the selected studies.

Business process correctness aims to guarantee that process models are syntactically and semantically correct. With the lowest number of contributions, this topic encompassed 6 studies (around 11\%): P29, P41, P60, P62, P68 and P79. One of the techniques in this group was a framework whose goal was not to check the correctness of a single business process model, but to ensure the soundness and semantic validity of a group of process variants (P41). Another approach used configurable versions of EPC models (C-EPC) and supported their adaptation via a mapping to a lawful regular EPC (P60). Additionally, two other approaches focused on configuring reference process models in a correctness-preserving manner (P62, P79).

An increase in flexibility is achieved when a process can be changed in a fast and easy form. Ten studies (almost 18\%) were identified with proposals focused on treating business process flexibility: P4, P5, P7, P8, P20, P21, P30, P44, P58 and P74. Some approaches employed business rules concepts (P5, P7, P20), with one of these splitting process behaviour into a stable and a flexible part (P74). An algebraic framework based on Algebra of System (AoS) was used to achieve the flexibility in business processes, with process models decomposed into different modules of knowledge and encoded as different algebraic domains (P8). In addition, a task mining technique was applied on a process model by reverse engineering it in a Petri net (P44)

Business process variability modelling studies investigated the graphical representation of variability, generally exploring a process modelling notation (e.g. EPC) or adapting a language from a different field (e.g. Feature Models). Twenty-four approaches (42\%) were included in this group: P3, P10, P12, P14-P17, P22, P23, P25, P37, P40, P43, P46, P48, P49, P51, P54, P55-P57, P63, P69 and P77. Examples of these contributions are the introduction of features in EPC models (P3, P22, P37, P57), a hierarchical representation method for UML 2.0 activity diagrams (P56) and, extensions of BPMN (P12, P49, P77) and MAP models (P14) with constructs supporting variability modelling. Some approaches emphasised the importance of notation independence, such as a framework which manages variability and supported process models reuse $(\mathrm{P} 50)$.

Approaches addressing business process similarity shared the goal of diagnosing commonalities and variations among business process models. Seven studies (12\%) were included in this group: P33, P38, P42, P52, P53, P67 and P72. One of the proposals focused on quantifying the similarity based on the sequence of activities holding for the process model (P52). Another 
technique classified processes as "relevant", "irrelevant" or "potentially relevant" to a search query model (P38). Additionally, to detect similarities between process models, an approach used comparisons of the linguistic structure of their elements (P42).

\section{RQ2.2: Is automated tool support available?}

This research question examined the availability of automated tool support among the selected studies. Less than half of the approaches $(45.6 \%, 26)$ provided a mechanism to automatically support their proposals: P4, P10, P16, P17, P19, P22, P23, P34, P36, P38, P40, P41, P42, P47, P48, P49, P50, P52, P53, P54, P57, P44, P60, P61, P62 and P68.

Sixteen (61.54\%) among 26 tools are free and open-source (P4, P16, P22, P23, P34, P38, P40, P42, P49, P50, P52, P53, P57, P61, P62, P68). These tools can be downloaded from dedicated websites, with manuals and tutorials. Additionally, among proprietary proposals (P10, P17, P19, P36, P41, P47, P48, P54, P44, P60), some were conceived as extensions or plug-ins for popular BPM suites, such as ARIS (P19, P36, P41, P60). By free offering the tools or improving popular BPMS researchers promote a wider adoption of their solutions by practitioners, since these can be applied in real scenarios.

\section{RQ2.3: How are the approaches for business process variability empirically evaluated?}

This sub-question focused on the number of approaches empirically analysed. It describes the methods used for assessing the solutions presented by the 57 studies identified in RQ2.1. Only 17 $(30 \%)$ of the solutions were experimented in practice: P15, P16, P17, P19, P22, P23, P33, P37, P38, P39, P46, P48, P50, P52, P54, P68 and P79.

Three different strategies were applied in the empirical evaluations, individually or in a combined form: case studies, experiments and surveys. Case study was the most popular method, being used to assess 14 proposals: P15, P16, P17, P19, P22, P23, P33, P39, P46, P48, P50, P54, P68 and P79. The industrial context was the preferred setting for carrying out case studies, with approaches being tested in automotive (P19 and P54), film (P22, P51 and P68) and medical (P54) domains, for instance. There are also case studies executed in a government setting (P23) and based on data obtained from a literature analysis (P46). Two studies used a multiple case study design (P19 and P54). In comparison with single data source studies, this allows an improved justification of findings while generating additional results, as remarked by Bratthall and Jørgensen [24].

Three studies (P16, P37 and P38) used an experimental design. Two of them executed multiple experiments, which is best thought of as replications. This increases the credibility of the study, allowing more robust conclusions to be drawn [25]. In addition, surveys were used by only two studies (P23 and P52), with different data collection techniques. A focus group was carried in one study (P23) as a means to test the practical usefulness of the approach, where the results were discussed with software providers and consultants. Another research (P52) distributed an on-line questionnaire among process modellers.

It is important to note the existence of studies using a mixed methods strategy: P16 proposed a research design with an experiment followed by a case study, while P23 conducted a case study and further evaluated additional aspects of the solution using a survey. In both cases, data collection and analysis were supported by quantitative and qualitative method. As discussed by Easterbrook et al. [23], this research strategy emerged in the recognition that all methods have deficiencies, and weaknesses of one empirical technique can be compensated for by the strengths of other techniques. 
The lack of empirical analysis in $70 \%$ of the solutions was balanced by the provision of examples. All studies proposing a novel approach presented examples illustrating its operation. These samples were classified in two groups: short examples $(45.6 \%)$ and working examples (54.4\%). The first category represents studies with brief descriptions of the approach operation, eventually contextualized with figures. On the other side, studies with working examples offered a detailed explanation of the method and simulated a real case with a step by step demonstration of the approach.

\subsection{RQ3: What are the current challenges within business process variability field?}

Applying this research question to the set of primary studies enabled us to comprehend the current direction within business process variability field and provide a diagnosis of its major issues. These problems represent challenges raised by academics and potential research opportunities. Based on inputs from P1, P6, P19, P20, P23, P27, P28, P32, P34, P36, P39, P41, P45, P46, P47, P50, P62, P73 and P77, we depict these challenges as follows.

Guarantee the correct configuration of a whole process family is a challenge which has received little attention. This implies on a difficult and time-consuming task: to ensure the correctness of all processes obtained from a particular configurable model (P41). A naive approach to treat this issue would require solving an exponential number of state-space problems (P34). Also, hiding and blocking mechanisms (P2, P24) applied on fragments of a process model may promote behavioural anomalies such as deadlocks and livelocks. This is exacerbated by the number of possibilities to configure a process model, the complex domain and data dependencies between configuration options (P34). Additionally, with manual methods for process configuration, analysts are left with the burden of ensuring the correctness of the customized models and of manually fixing errors (P50).

Business process flexibility requirements need to be addressed in order to decrease reaction time for process change. To ensure flexible business process support one must deal with a myriad of business requirements (P20). In addition, the identification, documentation and analysis of flexibility requirements are not trivial activities (P28). To treat these aspects, we identified a structure summarizing flexibility requirements to be handled by process-centred systems (P6). Also, it was addressed how the need for flexibility affects business process flexibility requirements (P32). These are relevant contributions to obtain flexibility in an automated setting. To achieve that, process design and realization mechanisms are required to preserve business invariants during changes (P73) and provide guidance for stakeholders to define flexible business processes $(\mathrm{P} 1)$.

Another challenge is to develop modelling techniques that consider the stimulus for change and not only capture the reactive part of flexibility. This involves recognizing context changes together with knowledge about which types of change lead to an increased flexibility and decreased reaction time (P28).

A major issue for reference modelling is the lack of sophisticated concepts and tools to support process reuse. Analysts must spend huge amounts of time on adjusting a standard solution to the individual needs of the organization (P23). Accordingly, the absence of an explicit representation of configuration possibilities and decisions generates an entirely manual individualization, with reference models merely as a source of inspiration (P62).

In the context of process similarity, a general concern is comparing templates to decide on which process variant to implement. Given the lack of an explicit representation of differences 
between similarly structured templates, manually finding the small differences can be a difficult and time-consuming task (P23).

There is a lack of adaptability in formalisms. Since business processes provide an integrated view over an organisation, modelling languages must enable the definition and selection of several aspects (e.g. tasks, resources) (P77). On the opposite direction, excessively describing business aspects within the configuration layer makes the instantiation of a model with a large number of variation points close to unmanageable (P50). Hence, a proper level of abstraction must be defined to minimize model complexity and interpretation problems.

A related challenge is choosing between specifying process variants within a single model and defining them in individual artefacts. In most cases neither the use of separate models for capturing different variants nor the description of variants using conditional branches constitutes a viable solution (P19). The first option results in a huge amount of redundant and unrelated model data. This complicates variant management (P45) and demands BPM tools to support variants modelling and maintenance $(\mathrm{P} 36, \mathrm{P} 39, \mathrm{P} 41)$. The definition of all process variants in a single structure makes variants hard-wired in the control flow logic. This strategy also generates a large model for a particular process family, which is difficult to comprehend and expensive to maintain (P19). No comprehensive solution is available to adequately model multiple process variants within a unique structure (P47). A potential solution to both cases could be the configuration of process models using explicit change operations and adjustment points (P19).

The adaptation of process models due to changing conditions has to be quick and precise ( $\mathrm{P} 2$, P12, P67, P76). The usual complex and continual transformations demand great ability from analysts. Frequently, analysts have to adapt process models while considering risks and costs involved in process configuration (P46). To address this challenging dynamic context, it is important to offer guidance and decision support during configuration activities. Despite the relevance of this theme, process configuration is generally performed in an ad-hoc basis guided by the analyst experience. Although some techniques have been proposed, such as the usage of questionnaires and domain analysis, these are mainly concerned with the elicitation of variability than the configuration procedure (P27). The lack of explicit links between variation points in the model and business needs turns difficult to estimate the impact of configuration decisions. The user must then possess expertise in the application domain and in the modelling notation (P50).

\section{DISCUSSION}

We provided in this paper an overview of relevant concepts for business process variability by summarizing theoretical background accumulated in the domain. This synthesis provides a catalogue of notions composing variability context and clarifies the connections among them. This analysis revealed that definitions on process variability were scattered at diverse studies, being employed in an inaccurate and redundant way. The concepts described in this initial taxonomy can produce a standard vocabulary. In this sense, it can be used to improve the dialogue among practitioners (i.e. communication between process analysts, designers, developers and users) and academics. Similar efforts have been conducted in studies P64, P65 and P75, which focused on process flexibility context to define patterns and taxonomies.

We found that a large majority of studies $(71 \%, 57)$ proposed solutions for process variability management. Their main focus was on representing variability within process models $(42 \%, 24)$. To treat this issue, most approaches proposed extensions to popular process modelling notations such as BPMN and EPC. Complementing this aspect, solutions supporting the configuration procedure and flexibility characteristics appeared as a second trend (18\%, 10 each). Some 
proposals for business process configuration emphasised the relevance of decision-making support by using questionnaires and decision tables. Among solutions addressing business process flexibility we perceived a predominance of modelling formalisms such as Algebra of Systems, Petri nets and business rules. Finally, business process correctness and similarity were addressed by only a few studies ( 6 and 7 proposals, respectively). Despite the low number of contributions, the proposed approaches were not in early stages of development. We identified, for instance, mature frameworks for ensuring well-formedness of a group of process variants and techniques to semantically evaluate similarities between process models.

Development efforts are centred on manipulating the variability with the insertion of variation points in process models. Process correctness and similarity have currently a potential lower priority in regards to variability representation, process configuration and flexibility aspects. A probable reason for this result is the origin of basic constructs from several approaches for process variability management in SPL field. While variability modelling and related concerns are consolidated in SPL approaches, the definition of well-formed product lines is a topic which is starting to be explored by the SPL community. The extent to which this issue is explored is still mostly type safety, i.e., syntactic. In SPL approaches, semantic issues are only beginning to be tackled automatically by the use of model checkers [26].

Almost $47 \%$ (26) of the 57 studies providing approaches for business process variability offered automated tool support. We argue that approaches are more powerful if they are supported by a software tool, since it offers guidance to process designers in handling business process variability. Otherwise, the use of the proposed methods tends to be time and resource consuming. Hence, it is more suitable to exploit automated tools as a means to obtain high quality process models, enable designers to evaluate the effects of the proposed solutions and, finally, use these tools as learning support for adopting the approaches. Positive aspects in the offered tools are that most of them were freely available $(61.5 \%, 16)$ and some of them were conceived as extensions of popular BPM tools $(15 \%, 4)$, which helps to broaden the dissemination of the correspondent methods.

Concerning empirical evidence of the approaches, we observed a low number of evaluations (32\%). This can be viewed as a considerable problem, since professionals often need empirical evidence to judge if the technique is suitable to their context [32]. Hence, the absence of evidence regarding practical effects of the approaches limits their acceptance. For researchers, these findings are relevant for replicating the evaluations and can serve as input to further investigate the applicability of the techniques with different strategies.

Our findings revealed a preponderance of qualitative research methods, which were employed in $84 \%$ (14) of the empirical assessments. This reflects the recent and growing adoption of qualitative methods in Software Engineering, Human-Computer Interaction and Information Systems fields, as stated by Seaman in [27]. A main advantage of qualitative research is providing researchers with richer and more informative data.

The qualitative strategies were composed by case studies and surveys, with a preponderance of the former (74\%). Although case studies cannot reach the scientific rigor of formal experiments, they can provide practitioners and researchers with sufficient information about the benefits offered by a specific technology to an organization or project, according to Kitchenham et al. [28]. Experiments were conducted by only a few studies $(16 \%, 3)$. This might be due to the difficulty to execute formal experiments when the degree of control is limited, which leads to small experiments in a real scenario. On the other hand, case studies avoid scale-up problems in industrial evaluations, which happen when changing from a laboratory to a real context [28]. 
We also noted the use of mixed methods in empirical assessments. Among the 3 experiments conducted (16\%), one of them was followed by a case study, adopting a mixed method approach. This highlights the relevance of qualitative studies to answer questions that involve variables which are difficult to quantify (e.g. "why" questions) and which have already being addressed by quantitative research [27]. In addition, one study executed the empirical evaluation by combining case study and survey strategies. Surveys combine advantages of experiments with those of case studies, such as replication that minimises the unusual results [28].

Our mapping study also investigated practical aspects of business process variability as a means to detail issues not yet addressed in the literature. We observed a clear demand for automatic support to verify the soundness of a business process variant obtained by process configuration. Also, reference models must be equipped with configuration facilities to act not as a single source of inspiration but rather as a configuration instrument. The variability represented in process models should involve additional aspects (e.g. organisational resources) while balancing expressiveness and complexity. Additionally, process configuration must be supported by mechanisms providing more guidance and BPM systems should handle requirements for process flexibility. We aimed to foster insights of future works in academic projects by highlighting these research gaps. These novel studies may trigger the improvement of existing approaches with a view to provide a greater support for business process variability.

\section{THREATS TO VALIDITY}

A potential risk is associated to the selection step of the search process. Although based on a predefined set of criteria, this stage was guided by the experience of the research team. Given that, relevant studies may have been missed, notwithstanding our aim to ensure the completeness of the selection. Additionally, during data extraction procedure, to answer the research questions it was necessary to interpret the subjective information provided by the studies in several occasions. This happened because many studies did not present objective details regarding the issues investigated. In order to prevent inaccuracies and minimize a potential bias, we discussed extracted data to reach a consensus. Additionally, the conclusions obtained by a given researcher were further evaluated by at least another member of the team.

Another potential threat to validity concerns the electronic databases employed in automatic search procedure. Natural limitations of search engines may have caused the loss of relevant papers. To mitigate this issue, a manual search was conducted to improve the quality of search results. Whitepapers, posters, summaries of articles, tutorials, panels, presentations and personal opinion papers were excluded from this review. Discarding this literature had probably no impact on research results, as this is unlikely to provide relevant and/or mature information.

\section{Conclusions}

Business process variability can be viewed as a result from the dynamism of the organisational and business environment. It is the ability of a process model to be adapted for use in a specific domain, employing existing knowledge and reducing response time and modelling efforts [29]. Variability management within BPM has been studied since the last decade, with a significant number of approaches reported. This paper aimed to investigate business process variability through a systematic mapping study. 
We have searched systematic mapping studies and literature reviews in the field to analyse the results obtained and make comparisons with our findings. As far as we are aware, As far as we are aware, [30] is the only survey in the field of business process variability, with a mainly technical view on the subject, exploring process reuse techniques and their limitations. Our work provides a wider view of the field, not only addressing approaches for process variability management but also providing a theoretical synthesis of this phenomenon and shedding light on research opportunities. This highlights its relevance to enable future variability research to be easily positioned within the comprehensive synthesis provided.

Since in this paper we focused on the design-time dimension of business process variability, in future work we plan to evaluate studies that deal exclusively with the runtime environment of variability. This is relevant to reveal issues associated with execution aspects of process variability, enrich our comprehension of this phenomenon and improve the analysis of the support offered by available approaches.

Finally, we propose some specific lines of research based on the findings reported in this study. An initial idea would be to conduct expert surveys involving experts from the academia and industry to refine the conclusions obtained by this research. This initiative could be accomplished through focus group sessions, which would not only provide useful insights on our findings but also foster discussions among participants.

We also suggest the execution of backward reference searches. This procedure consists in reviewing the references of primary studies. This activity should improve the results of this review, since it enables a wide coverage of directly relevant studies. Additionally, backward authors search could be executed and provide fruitful information from authors' prior works. Finally, an important further research is the development of a formal taxonomy for business process variability. This structure would facilitate the exploration of each notion linked to business process variability issue.

\section{REFERENCES}

[1] Marella, A. (2010) "Featuring Process Flexibility in Highly Dynamic Environments", Tech. Rep., Dipartimento di Informatica e Sistemistica Antonio Ruberti, Sapienza Universit di Roma, Roma.

[2] ABPMP (2009) "Guide to the Business Process Management Common Body of Knowledge".

[3] Rinderle, S. B., Reichert, M. U., Dadam, P. (2004) "Correctness Criteria for Dynamic Changes in Workflow Systems: a Survey, Data and Knowledge Engineering”, 50 (1), pp. 9-34.

[4] Wegmann, A. (2006) "Flexibility: Change, but Change What?", Proc. of Workshop on Business Process Modelling, Development and Support.

[5] Mller, J. (2009) "Supporting Change in Business Process Models Using Pattern- Based Constraints", Enterprise, Business-Process and Information Systems Modeling, pp. 27-32.

[6] Soffer, P. (2004) "Analyzing the Scope of a Change in a Business Process Model”, Proc. of Int'1 Conference on Advanced Information Systems Engineering Workshops.

[7] Goedertier, S., Vanthienen, J. "Compliant and Flexible Business Processes with Business Rules", Proc. of Workshop on Business Process Modelling, Development, and Support.

[8] Eijndhoven, T., Iacob, M., Ponisio, M. (2008) "Achieving Business Process Flexibility with Business Rules”, Proc. of Int'1 IEEE Enterprise Distributed Object Computing Conference.

[9] Regev, G., Soffer, P. Schmidt, R. (2006) "Taxonomy of Flexibility in Business Processes”, Proc. of Workshop on Business Process Modelling, Development, and Support.

[10] Vervuurt, M. (2007) "Modeling Business Process Variability", Master Thesis.

[11] La Rosa, M., Dumas, M., ter Hofstede, A., Mendling, J. (2011) "Configurable Multi-Perspective Business Process Models, Information Systems 36, pp. 313-340.

[12] Van der Aalst, W., Dumas, M., Gottschalk, F., ter Hofstede, A., La Rosa, M., Mendling, J. (2010) "Preserving Correctness During Business Process Model Configuration", Formal Aspects of Computing 22, pp. 459-482. 
[13] La Rosa, M., van der Aalst, W., Dumas, M., ter Hofstede, A. (2009) "Questionnaire-Based Variability Modeling for System Configuration”, Soft. and Systems Modeling 8, pp. 251-274.

[14] Rolland, C., Nurcan, S. (2010) "Business Process Lines to Deal with the Variability", Proc. of HICSS, pp. 1-10.

[15] Boffoli, N., Caivano, D., Castelluccia, D., Maggi, F. M., Visaggio, G. (2008) "Business Process Lines to Develop Service-Oriented Architectures Through the Software Product Lines Paradigm", Proc. of Software Product Line Conference, pp. 143-147.

[16] Hallerbach, A., Bauer, T., Reichert, M. "Capturing Variability in Business Process Models: the Provop Approach”, Journal of Software Maintenance 22 (6-7), pp. 519-546.

[17] Kulkarni, V., Bara, S. (2010) "Business Process Families Using Model-Driven Techniques", Proc. of Business Process Management Workshops, pp. 314-320.

[18] Budgen, D., Turner, M., Brereton, P., Kitchenham, B. (2008) "Using Mapping Studies in Software Engineering", Proc. of PPIG, pp. 195-204.

[19] Kitchenham, B., Budgen, D., Brereton, O. (2011) "Using Mapping Studies as the Basis for Further Research: A Participant-observer Case Study", Information and Soft. Technology 53 (6), pp. 638651.

[20] Kitchenham, B., Dyba, T., Jorgensen, M. (2004) "Evidence-based Software Engineering", Proc. of the Int'l Conference on Software Engineering, pp. 273-281.

[21] Petersen, K., Feldt, R., Mujtaba, S., Mattsson, M. (2008) "Systematic Mapping Studies in Software Engineering”, Proc. of Int'l Conference on Evaluation and Assessment in Soft. Eng., pp. 68-77.

[22] Kitchenham, B. (2010) "What's up with Software Metrics? - A Preliminary Mapping Study", J. Syst. Softw. 83 (1), pp. 37-51.

[23] Easterbrook, S., Singer, J., Storey, M., Damian, D. (2008) "Guide to Advanced Empirical Software Engineering", Selecting Empirical Methods for Soft. Engineering Research, Springer.

[24] Bratthall, L., Jørgensen, M. (2001) "Can you Trust a Single Data Source Exploratory Software Engineering Case Study?”, Empirical Softw. Eng. 7 (1), pp. 705-754.

[25] Shull, F., Basili, V., Carver, J., Maldonado, J. (2002) "Replicating Software Engineering Experiments: Addressing the Tacit Knowledge Problem”, Proc. of Int'1 Symposium on Empirical Software Engineering, pp. 7-16.

[26] Classen, A., Heymans, P., Schobbens, P., Legay, A. (2010) "Symbolic Model Checking of Software Product Lines”, Proc. of Int'l Conference of Software Engineering, 321-330.

[27] Seaman, C. B. (1999) "Qualitative Methods in Empirical Studies of Software Engineering”, IEEE Trans. Softw. Eng. 25 (4), pp. 557-572.

[28] Kitchenham, B., Pickard, L., Pfleeger, S. L. (1995) "Case Studies for Method and Tool Evaluation", IEEE Software 12 (4), pp. 52-62.

[29] Soffer, P., Reinhartz-Berger, I., Sturm, A. (2007) "Facilitating Reuse by Specialization of Reference Models for Business Process Design", Proc. of Workshop on Business Process Modeling, Development, and Support, pp. 339-347.

[30] Fantinato, M., Toledo, M. B. F., Thom, L. H., Gimenes, I. M. S., Rocha, R. S., Garcia, D. Z. G. (2012) “A Survey on Reuse in the Business Process Management Domain”. Int'1 Journal of Business Process Integration and Management 6, pp. 52-76.

[31] Rosenmller, M., Siegmund, N., Apel, S., Saak, G. (2011) "Flexible Feature Binding in Software Product Lines", Automated Software Engineering 18 (2), pp. 163-197.

[32] Patil, M.V., Yogi, A.M.N. (2011) "Importance of Data Collection and Validation for Systematic Software Development Process”. Int'l Journal of Computer Science \& Inf. Technology, 3 (2).

[33] Aly, A.A., Deris, S.B., Zaki, N. (2011) "Research Review for Digital Image Segmentation Techniques". Int'l Journal of Computer Science \& Inf. Technology 3 (5).

[34] Kara, M. (2012) "Review on Common Criteria as a Secure Software Development Model". Int'l Journal of Computer Science \& Inf. Technology, 4 (2). 


\section{Appendix A - Primary Studies}

\begin{tabular}{|c|c|c|c|}
\hline ID & Title & Author(s) & Venue \\
\hline P1 & $\begin{array}{l}\text { A benchmarking framework for } \\
\text { methods to design flexible } \\
\text { business processes }\end{array}$ & $\begin{array}{l}\text { F. Daoudi and } \mathrm{S} \text {. } \\
\text { Nurcan }\end{array}$ & $\begin{array}{l}\text { Software Process: Improvement and } \\
\text { Practice, } 2007\end{array}$ \\
\hline $\mathrm{P} 2$ & $\begin{array}{l}\text { A Conceptual Framework for } \\
\text { Intention Driven Flexible } \\
\text { Workflow Modeling }\end{array}$ & S. Nurcan & $\begin{array}{l}\text { Workshop on Business Modeling, } \\
\text { Development and Support - Int'1 } \\
\text { Conference on Advanced } \\
\text { Information Systems Engineering, } \\
2004\end{array}$ \\
\hline P3 & $\begin{array}{l}\text { A Configurable Reference } \\
\text { Modelling Language }\end{array}$ & $\begin{array}{l}\text { M. Rosemann and W. } \\
\text { M. P. van der Aalst }\end{array}$ & Information Systems, 2007 \\
\hline P4 & $\begin{array}{l}\text { A flexible, Object-centric } \\
\text { Approach for Business Process } \\
\text { Modelling }\end{array}$ & $\begin{array}{l}\text { G. Redding, M. } \\
\text { Dumas, A. H. } \\
\text { Hofstede and A. } \\
\text { Iordachescu }\end{array}$ & $\begin{array}{l}\text { Service Oriented Computing and } \\
\text { Applications , } 2010\end{array}$ \\
\hline P5 & $\begin{array}{l}\text { A Role-Based Approach for } \\
\text { Modeling Flexible Business } \\
\text { Processes }\end{array}$ & $\begin{array}{l}\text { O. Saidani and } \mathrm{S} \text {. } \\
\text { Nurcan }\end{array}$ & $\begin{array}{l}\text { Int'l Conference on Advanced } \\
\text { Information Systems Engineering, } \\
2006\end{array}$ \\
\hline P6 & $\begin{array}{l}\text { A Survey on the Flexibility } \\
\text { Requirements Related to Business } \\
\text { Processes and Modeling Artifacts }\end{array}$ & S. Nurcan & $\begin{array}{l}\text { Hawaii Int'l Conference on System } \\
\text { Sciences Engineering, } 2008\end{array}$ \\
\hline P7 & $\begin{array}{l}\text { Achieving Business Process } \\
\text { Flexibility with Business Rules }\end{array}$ & $\begin{array}{l}\text { T. van Eijndhoven, } \\
\text { M. E. Iacob } \\
\text { and M. L. Ponisio }\end{array}$ & $\begin{array}{l}\text { Int'1 IEEE Enterprise Distributed } \\
\text { Object Computing Conference, } 2008\end{array}$ \\
\hline P8 & $\begin{array}{l}\text { Achieving flexibility in Business } \\
\text { Process Modeling Using an } \\
\text { Algebraic Language }\end{array}$ & $\begin{array}{l}\text { L. Xiao, B.H.Y. Koo } \\
\text { and L. Zheng }\end{array}$ & $\begin{array}{l}\text { Int'1 Conference on Model-Based } \\
\text { Systems Engineering, } 2009\end{array}$ \\
\hline P9 & $\begin{array}{l}\text { Alternative Approaches for } \\
\text { Workflow Similarity }\end{array}$ & $\begin{array}{l}\text { A. Wombacher and } \\
\text { C. Li }\end{array}$ & $\begin{array}{l}\text { IEEE Int'l Conference on Services } \\
\text { Computing, } 2010\end{array}$ \\
\hline P10 & $\begin{array}{l}\text { An Automation Support for } \\
\text { Creating Configurable Process } \\
\text { Models }\end{array}$ & $\begin{array}{l}\text { W. Derguech and S. } \\
\text { Bhiri }\end{array}$ & $\begin{array}{l}\text { Int'l Conference on Web } \\
\text { Information System Engineering, } \\
2011\end{array}$ \\
\hline P11 & $\begin{array}{l}\text { Analyzing the Scope of a Change } \\
\text { in a Business Process Model }\end{array}$ & P. Soffer & $\begin{array}{l}\text { Workshop on Business Modeling, } \\
\text { Development and Support -Int' } \\
\text { Conference on Advanced } \\
\text { Information Systems Engineering, } \\
2004\end{array}$ \\
\hline P12 & $\begin{array}{l}\text { Business Process Families Using } \\
\text { Model-Driven Techniques }\end{array}$ & $\begin{array}{l}\text { V. Kulkarni and S. } \\
\text { Barat }\end{array}$ & $\begin{array}{l}\text { Workshop on Reuse in Business } \\
\text { Process Management - Business } \\
\text { Process Management Conference, } \\
2010\end{array}$ \\
\hline P13 & $\begin{array}{l}\text { Business Process Flexibility: } \\
\text { Weick's Organizational Theory to } \\
\text { the Rescue }\end{array}$ & $\begin{array}{l}\text { G. Regev and A. } \\
\text { Wegmann }\end{array}$ & $\begin{array}{l}\text { Business Modeling, Development } \\
\text { and Support Workshop - Int'l } \\
\text { Conference on Advanced } \\
\text { Information Systems Engineering, } \\
2006\end{array}$ \\
\hline P14 & $\begin{array}{l}\text { Business Process Lines to Deal } \\
\text { with the Variability }\end{array}$ & $\begin{array}{l}\text { C. Rolland and } \mathrm{S} \text {. } \\
\text { Nurcan }\end{array}$ & $\begin{array}{l}\text { Hawaii Int'l Conference on System } \\
\text { Sciences, } 2010\end{array}$ \\
\hline P15 & $\begin{array}{l}\text { Business Process Lines to develop } \\
\text { Service-Oriented Architectures } \\
\text { through the Software Product } \\
\text { Lines paradigm }\end{array}$ & $\begin{array}{l}\text { N. Boffoli, D. } \\
\text { Caivano, D. } \\
\text { Castelluccia, F. M. } \\
\text { Maggi and G. } \\
\text { Visaggio }\end{array}$ & $\begin{array}{l}\text { Software Product Line Conference, } \\
2008\end{array}$ \\
\hline P16 & $\begin{array}{l}\text { Business Process Model Merging: } \\
\text { An Approach to Business Process } \\
\text { Consolidation }\end{array}$ & $\begin{array}{l}\text { M. La Rosa, M. } \\
\text { Dumas, R. Kaarik } \\
\text { and R. Dijkman }\end{array}$ & $\begin{array}{l}\text { QUT ePrints Technical Report } \\
38241 \text {, Queensland University of } \\
\text { Technology, } 2008\end{array}$ \\
\hline P17 & $\begin{array}{l}\text { Business Process Modeling Aware } \\
\text { to the Environment }\end{array}$ & $\begin{array}{l}\text { N. Boffoli, D. } \\
\text { Castelluccia, F. M. } \\
\text { Maggi and R. Rutilo }\end{array}$ & $\begin{array}{l}\text { Int'l Conference on Evaluation of } \\
\text { Novel Approaches to Software } \\
\text { Engineering, } 2008\end{array}$ \\
\hline P18 & $\begin{array}{l}\text { Business Process Modelling and } \\
\text { Flexibility }\end{array}$ & S. Nurcan & $\begin{array}{l}\text { Int'l Conference on Interoperability } \\
\text { for Enterprise Software and } \\
\text { Applications, } 2007\end{array}$ \\
\hline
\end{tabular}


International Journal of Computer Science \& Information Technology (IJCSIT) Vol 5, No 1, February 2013

\begin{tabular}{|c|c|c|c|}
\hline P19 & $\begin{array}{l}\text { Capturing Variability in Business } \\
\text { Process Models - the Provop } \\
\text { Approach }\end{array}$ & $\begin{array}{l}\text { A. Hallerbach, T. } \\
\text { Bauer and M. Reichert }\end{array}$ & $\begin{array}{l}\text { Journal of Software Maintenance } \\
\text { and Evolution: Research and } \\
\text { Practice, 2010 }\end{array}$ \\
\hline P20 & $\begin{array}{l}\text { Compliant and Flexible Business } \\
\text { Processes with Business Rules }\end{array}$ & $\begin{array}{l}\text { S. Goedertier and } \mathrm{J} . \\
\text { Vanthienen }\end{array}$ & $\begin{array}{l}\text { CEUR Workshop and Practice, } \\
2006\end{array}$ \\
\hline $\mathrm{P} 21$ & $\begin{array}{l}\text { Conceptual Method for Flexible } \\
\text { Business Process }\end{array}$ & $\begin{array}{l}\text { A. Bentellis and } \mathrm{Z} \text {. } \\
\text { Boufada }\end{array}$ & $\begin{array}{l}\text { World Academy of Science, } \\
\text { Engineering and Technology, } 2008\end{array}$ \\
\hline P22 & $\begin{array}{l}\text { Configurable multi-perspective } \\
\text { business process models }\end{array}$ & $\begin{array}{l}\text { M. La Rosa, M. } \\
\text { Dumas, A.H.M. ter } \\
\text { Hofstede, and J. } \\
\text { Mendling }\end{array}$ & Information Systems, 2011 \\
\hline P23 & Configurable Process Models & F. Gottschalk & $\begin{array}{l}\mathrm{PhD} \text { thesis, Technische Universiteit } \\
\text { Eindhoven, } 2009\end{array}$ \\
\hline P24 & $\begin{array}{l}\text { Configurable Process Models: A } \\
\text { Foundational Approach }\end{array}$ & $\begin{array}{l}\text { F. Gottschalk and } \mathrm{M} \text {. } \\
\text { H. Jansen-vullers }\end{array}$ & $\begin{array}{l}\text { Reference Modelling Conference, } \\
2006\end{array}$ \\
\hline P25 & $\begin{array}{l}\text { Configurable Process Models as a } \\
\text { Basis for Reference Modeling }\end{array}$ & $\begin{array}{l}\text { W.M.P. van der } \\
\text { Aalst, A. Dreiling } \\
\text { M. Rosemann and } \\
\text { M.H. Jansen-Vullers }\end{array}$ & $\begin{array}{l}\text { Workshop on Business Process } \\
\text { Reference Model - Business Process } \\
\text { Management Conference, } 2005\end{array}$ \\
\hline P26 & $\begin{array}{l}\text { Configurative Process Modeling: } \\
\text { Outlining an Approach to } \\
\text { Increased Business Process Model } \\
\text { Usability }\end{array}$ & Jrg Becker & $\begin{array}{l}\text { Information Resources Management } \\
\text { Association Int'l Conference, } 2004\end{array}$ \\
\hline P27 & $\begin{array}{l}\text { Configuring the Variability of } \\
\text { Business Process Models Using } \\
\text { Non-Functional Requirements }\end{array}$ & $\begin{array}{l}\text { E. Santos, J. Pimentel, } \\
\text { J. Castro, J. Snchez } \\
\text { and O. Pastor }\end{array}$ & $\begin{array}{l}\text { Exploring Modelling Methods for } \\
\text { Systems Analysis and Design - } \\
\text { Conference on Advanced } \\
\text { Information Systems Engineering, } \\
2010\end{array}$ \\
\hline P28 & $\begin{array}{l}\text { Context-aware Process Design } \\
\text { Exploring the Extrinsic Drivers } \\
\text { for Process Flexibility }\end{array}$ & $\begin{array}{l}\text { M. Rosemann and } \mathrm{J} \text {. } \\
\text { Recker }\end{array}$ & $\begin{array}{l}\text { Int'l Conference on Advanced } \\
\text { Information Systems Engineering, } \\
2006\end{array}$ \\
\hline P29 & $\begin{array}{l}\text { Correctness of Business Process } \\
\text { Models with Roles and Objects }\end{array}$ & $\begin{array}{l}\text { J. Mendling, M. La } \\
\text { Rosa, A.H.M ter } \\
\text { Hofstede }\end{array}$ & QUT ePrints Technical Report, 2008 \\
\hline P30 & $\begin{array}{l}\text { Defining Adaptation Constraints } \\
\text { for Business Process Variants }\end{array}$ & $\begin{array}{l}\text { R. Lu, S. Sadiq, G. } \\
\text { Governatori and X. } \\
\text { Yang }\end{array}$ & $\begin{array}{l}\text { Int'1 Conference on Business } \\
\text { Information Systems, } 2009\end{array}$ \\
\hline P31 & $\begin{array}{l}\text { Defining Business Process } \\
\text { Flexibility with the Help of } \\
\text { Invariants }\end{array}$ & $\begin{array}{l}\text { G. Regev, I. Bider and } \\
\text { A. Wegmann }\end{array}$ & $\begin{array}{l}\text { Software Process: Improvement and } \\
\text { Practice, } 2007\end{array}$ \\
\hline P32 & $\begin{array}{l}\text { Defining Requirements for } \\
\text { Business Process Flexibility }\end{array}$ & $\begin{array}{l}\text { K. Kumar and M. M. } \\
\text { Narasipuram }\end{array}$ & $\begin{array}{l}\text { Workshop on Business Process } \\
\text { Modelling, Development, and } \\
\text { Support -Conference on Advanced } \\
\text { Information Systems Engineering, } \\
2006\end{array}$ \\
\hline P33 & $\begin{array}{l}\text { Diagnosing Differences between } \\
\text { Business Process Models }\end{array}$ & R. M. Dijkman & $\begin{array}{l}\text { Int'l Conference on Business Process } \\
\text { Management, } 2008\end{array}$ \\
\hline P34 & $\begin{array}{l}\text { Ensuring Correctness During } \\
\text { Process Configuration via Partner } \\
\text { Synthesis }\end{array}$ & $\begin{array}{l}\text { W.M.P. van der } \\
\text { Aalst, N. Lohmann } \\
\text { and M. La Rosa }\end{array}$ & BPM Center Report BPM, 2011 \\
\hline P35 & $\begin{array}{l}\text { Exploring the Dimensions of } \\
\text { Variability - a Requirements } \\
\text { Engineering Perspective }\end{array}$ & $\begin{array}{l}\text { W.M.P. S. Liaskos, L. } \\
\text { Jiang, A. Lapouchnian, } \\
\text { Y. Wang, Y. Yu and } \\
\text { J.C.S.d.P. Leite, J. } \\
\text { Mylopoulos }\end{array}$ & $\begin{array}{l}\text { Int'1 Workshop on Variability } \\
\text { Modelling of Software-intensive } \\
\text { Systems, } 2007\end{array}$ \\
\hline P36 & $\begin{array}{l}\text { Extending a Business Process } \\
\text { Modeling Tool with Process } \\
\text { Configuration Facilities: The } \\
\text { Provop Demonstrator }\end{array}$ & $\begin{array}{l}\text { M. Reichert, S. } \\
\text { Rechtenbach, A. } \\
\text { Hallerbach, and T. } \\
\text { Bauer }\end{array}$ & $\begin{array}{l}\text { Int'l Conference on Business Process } \\
\text { Management, } 2009\end{array}$ \\
\hline P37 & $\begin{array}{l}\text { Extending the Adaptability of } \\
\text { Reference Models }\end{array}$ & $\begin{array}{l}\text { I. Reinhartz-Berger, } \\
\text { P. Soffer and A. } \\
\text { Sturm }\end{array}$ & $\begin{array}{l}\text { IEEE Transactions on Systems, Man } \\
\text { and, Cybernetics, Part Ä: Systems } \\
\text { and Humans, } 2010\end{array}$ \\
\hline P38 & $\begin{array}{l}\text { Fast Business Process Similarity } \\
\text { Search with Feature-based } \\
\text { Similarity Estimation }\end{array}$ & $\begin{array}{l}\text { Z. Yan, R. Dijkman } \\
\text { and P. Grefen }\end{array}$ & $\begin{array}{l}\text { Int'l Conference on On the Move to } \\
\text { Meaningful Internet Systems, } 2010\end{array}$ \\
\hline
\end{tabular}


International Journal of Computer Science \& Information Technology (IJCSIT) Vol 5, No 1, February 2013

\begin{tabular}{|c|c|c|c|}
\hline P39 & $\begin{array}{l}\text { Flexible Process Modeling } \\
\text { Through Decision Tables }\end{array}$ & $\begin{array}{l}\text { N. Boffoli, D. } \\
\text { Castelluccia, F. M. } \\
\text { Maggi, and R. Rutilo }\end{array}$ & $\begin{array}{l}\text { IASTED Int'l Conference on } \\
\text { Software Engineering, } 2008\end{array}$ \\
\hline P40 & $\begin{array}{l}\text { From Feature Models to Business } \\
\text { Processes Tables }\end{array}$ & $\begin{array}{l}\text { I. Montero, J. Pena } \\
\text { and A. Ruiz-ortes }\end{array}$ & $\begin{array}{l}\text { IEEE Int'l Conference on Services } \\
\text { Computing, } 2008\end{array}$ \\
\hline P41 & $\begin{array}{l}\text { Guaranteeing Soundness of } \\
\text { Configurable Process Variants in } \\
\text { Provop }\end{array}$ & $\begin{array}{l}\text { A. Hallerbach, T. } \\
\text { Bauer and M. } \\
\text { Reichert }\end{array}$ & $\begin{array}{l}\text { IEEE Conference on Commerce and } \\
\text { Enterprise Computing, } 2009\end{array}$ \\
\hline P42 & $\begin{array}{l}\text { How To Detect Semantic Business } \\
\text { Process Model Variants? }\end{array}$ & $\begin{array}{l}\text { A. Koschmider and A. } \\
\text { Oberweis }\end{array}$ & $\begin{array}{l}\text { ACM symposium on Applied } \\
\text { computing SAC, } 2007\end{array}$ \\
\hline P43 & $\begin{array}{l}\text { Improving Business Process } \\
\text { Models with Reference Models in } \\
\text { Business-Driven Development }\end{array}$ & $\begin{array}{l}\text { J. M. Kster, J. Koehler } \\
\text { and K. Ryndina }\end{array}$ & $\begin{array}{l}\text { Int'1 Workshop on Business Process } \\
\text { Design - Business Process } \\
\text { Management Conference, } 2006\end{array}$ \\
\hline P44 & $\begin{array}{l}\text { Incremental Workflow Mining for } \\
\text { Process Flexibility }\end{array}$ & $\begin{array}{l}\text { E. Kindler, V. Rubin } \\
\text { and W. Schfer }\end{array}$ & $\begin{array}{l}\text { Workshop on Business Process } \\
\text { Modelling, Development, and } \\
\text { Support - Conference on Advanced } \\
\text { Information Systems Engineering, } \\
2006\end{array}$ \\
\hline $\mathrm{P} 45$ & $\begin{array}{l}\text { Issues in Modeling Process } \\
\text { Variants with Provop }\end{array}$ & $\begin{array}{l}\text { A. Hallerbach, T. } \\
\text { Bauer and M. } \\
\text { Reichert }\end{array}$ & $\begin{array}{l}\text { Int'1 Workshop on Business Process } \\
\text { Design - Business Process } \\
\text { Management Conference, } 2008\end{array}$ \\
\hline P46 & $\begin{array}{l}\text { Managing Business Process } \\
\text { Flexibility and Reuse Through } \\
\text { Business Process Lines }\end{array}$ & $\begin{array}{l}\text { N. Boffoli, M. } \\
\text { Cimitile and F. Maria } \\
\text { Maggi }\end{array}$ & $\begin{array}{l}\text { Conference on Software and Data } \\
\text { Technologies } 2009\end{array}$ \\
\hline P47 & $\begin{array}{l}\text { Managing Process Variants in the } \\
\text { Process Life Cycle }\end{array}$ & $\begin{array}{l}\text { A. Hallerbach, T. } \\
\text { Bauer and M. } \\
\text { Reichert }\end{array}$ & $\begin{array}{l}\text { Technical Report. University of } \\
\text { Twente, Enschede, The Netherlands, } \\
2007\end{array}$ \\
\hline P48 & $\begin{array}{l}\text { Managing SOA System Variation } \\
\text { through Business Process Lines } \\
\text { and Process Oriented } \\
\text { Development }\end{array}$ & $\begin{array}{l}\text { N. Boffoli, M. } \\
\text { Cimitile, F. M. } \\
\text { Maggi, } \\
\text { and G. Visaggio }\end{array}$ & $\begin{array}{l}\text { Workshop on Service-Oriented } \\
\text { Architectures and Software Product } \\
\text { Lines, } 2009\end{array}$ \\
\hline P49 & $\begin{array}{l}\text { Managing Variability in Business } \\
\text { Processes: an Aspect-oriented } \\
\text { Approach }\end{array}$ & $\begin{array}{l}\text { I. Machado, R. } \\
\text { Bonifcio, V. Alves, L. } \\
\text { Turnes, and G. } \\
\text { Machado }\end{array}$ & $\begin{array}{l}\text { Int'l Workshop on Early Aspects, } \\
2011\end{array}$ \\
\hline P50 & $\begin{array}{l}\text { Managing Variability in Process- } \\
\text { Aware Information Systems - PhD } \\
\text { Thesis }\end{array}$ & M. La Rosa & $\begin{array}{l}\text { Queensland University of } \\
\text { Technology, Brisbane, Australia, } \\
2009\end{array}$ \\
\hline P51 & $\begin{array}{l}\text { Managing Variability in Workflow } \\
\text { with Feature Model Composition } \\
\text { Operators }\end{array}$ & $\begin{array}{l}\text { M. Acher, P. Collet, P. } \\
\text { Lahire and R. France }\end{array}$ & $\begin{array}{l}\text { Int'l Conference on Software } \\
\text { Composition, } 2010\end{array}$ \\
\hline P52 & $\begin{array}{l}\text { Measuring Similarity between } \\
\text { Business Process Models }\end{array}$ & $\begin{array}{l}\text { B. Dongen, R. } \\
\text { Dijkman and } \mathrm{J} \text {. } \\
\text { Mendling }\end{array}$ & $\begin{array}{l}\text { Int'l Conference on Advanced } \\
\text { Information Systems Engineering, } \\
2008\end{array}$ \\
\hline P53 & $\begin{array}{l}\text { Measuring Similarity between } \\
\text { Semantic Business Process } \\
\text { Models }\end{array}$ & $\begin{array}{l}\text { M. Ehrig, A. } \\
\text { Koschmider and A. } \\
\text { Oberweis }\end{array}$ & $\begin{array}{l}\text { Asia-Pacific Conference on } \\
\text { Conceptual Modelling, } 2007\end{array}$ \\
\hline P54 & $\begin{array}{l}\text { Mining business process variants: } \\
\text { Challenges, scenarios, algorithms }\end{array}$ & $\begin{array}{l}\text { C. Li, M. Reichert and } \\
\text { A. Wombacher }\end{array}$ & $\begin{array}{l}\text { Data \& Knowledge Engineering, } \\
2011\end{array}$ \\
\hline P55 & $\begin{array}{l}\text { Mining Reference Process Models } \\
\text { and Their Configurations }\end{array}$ & $\begin{array}{l}\text { F. Gottschalk, Wil M. } \\
\text { Aalst, and } \\
\text { M. H. Jansen-Vullers }\end{array}$ & $\begin{array}{l}\text { OTM Confederated Int'1 Workshops } \\
\text { and Posters on On the Move to } \\
\text { Meaningful Internet Systems, } 2008\end{array}$ \\
\hline P56 & $\begin{array}{l}\text { Modeling Variability in Business } \\
\text { Process Models Using UML }\end{array}$ & $\begin{array}{l}\text { M. Razavian and R. } \\
\text { Khosravi }\end{array}$ & $\begin{array}{l}\text { Int'l Conference on Information } \\
\text { Technology: New Generations, } \\
2008\end{array}$ \\
\hline P57 & $\begin{array}{l}\text { Modelling Business Process } \\
\text { Variability - Masters thesis }\end{array}$ & M. Vervuurt & University of Twente, 2007 \\
\hline P58 & $\begin{array}{l}\text { On Managing Business Processes } \\
\text { Variants }\end{array}$ & $\begin{array}{l}\text { R. Lu, S. Sadiq and } \\
\text { G. Governatori }\end{array}$ & $\begin{array}{l}\text { Data \& Knowledge Engineering, } \\
2009\end{array}$ \\
\hline P59 & $\begin{array}{l}\text { On the Notion of Flexibility in } \\
\text { Business Processes }\end{array}$ & P. Soffer & $\begin{array}{l}\text { Workshop on Business Process } \\
\text { Modeling, Design and Support - Int'1 } \\
\text { Conference on Advanced } \\
\text { Information Systems Engineering, } \\
2005\end{array}$ \\
\hline
\end{tabular}


International Journal of Computer Science \& Information Technology (IJCSIT) Vol 5, No 1, February 2013

\begin{tabular}{|c|c|c|c|}
\hline P60 & $\begin{array}{l}\text { On the Syntax of Reference } \\
\text { Model Configuration - } \\
\text { Transforming the C-EPC into } \\
\text { Lawful EPC Models }\end{array}$ & $\begin{array}{l}\text { J. Recker, M. } \\
\text { Rosemann, W. M. P. } \\
\text { van der Aalst and J. } \\
\text { Mendling }\end{array}$ & $\begin{array}{l}\text { Workshop on Business Process } \\
\text { Reference Models - Business } \\
\text { Process Management Conference, } \\
2005\end{array}$ \\
\hline P61 & $\begin{array}{l}\text { Partial Process Models to Manage } \\
\text { Business Process Variants }\end{array}$ & $\begin{array}{l}\text { E. Pascalau, A. Awad, } \\
\text { S. Sakr and } \\
\text { M. Weske }\end{array}$ & $\begin{array}{l}\text { Int'1 Journal of Business Process } \\
\text { Integration and Management, } 2011\end{array}$ \\
\hline P62 & $\begin{array}{l}\text { Preserving Correctness During } \\
\text { Business Process Model } \\
\text { Configuration }\end{array}$ & $\begin{array}{l}\text { W. M.P. van der } \\
\text { Aalst, M. Dumas, F. } \\
\text { Gottschalk and A. H. } \\
\text { M. ter Hofstede, M. La } \\
\text { Rosa, J. Mendling }\end{array}$ & Formal Aspects of Computing, 2010 \\
\hline P63 & $\begin{array}{l}\text { Process Family Engineering - } \\
\text { Modeling Variant-rich Processes }\end{array}$ & $\begin{array}{l}\text { J.Bayer, W. Buhl, C. } \\
\text { Giese, T. Lehner, } \\
\text { A. Ocampo, F. } \\
\text { Puhlmann, E. Richter, } \\
\text { A. Schnieders, J. } \\
\text { Weiland and M. } \\
\text { Weske }\end{array}$ & $\begin{array}{l}\text { PESOA (Process Family } \\
\text { Engineering in Service-Oriented } \\
\text { Applications) - Report TR, } 2005\end{array}$ \\
\hline P64 & Process Flexibility Patterns & $\begin{array}{l}\text { N. Mulyar, W.M.P. } \\
\text { van der Aalst and N. } \\
\text { Russell }\end{array}$ & $\begin{array}{l}\text { Technical report, BETA Working } \\
\text { Paper Series, } 2008\end{array}$ \\
\hline P65 & $\begin{array}{l}\text { Process Flexibility: a Survey of } \\
\text { Contemporary Approaches }\end{array}$ & $\begin{array}{l}\text { M. H. Schonenberg, } \\
\text { R. S. Mans, N. C. } \\
\text { Russell and N. A. } \\
\text { Mulyar }\end{array}$ & $\begin{array}{l}\text { 8th Int'I Workshop on Enterprise } \\
\text { and Organizational Modeling And } \\
\text { Simulation - Int'l Conference on } \\
\text { Advanced Information Systems } \\
\text { Engineering, 2008 }\end{array}$ \\
\hline P66 & $\begin{array}{l}\text { Process Flexibility: Design, } \\
\text { Evaluation, and Applications }\end{array}$ & $\begin{array}{l}\text { Mabel C. Chou, } \\
\text { Chung-Piaw Teo and } \\
\text { Huan Zheng }\end{array}$ & $\begin{array}{l}\text { Flexible Services and Manufacturing } \\
\text { Journal, } 2008\end{array}$ \\
\hline P67 & $\begin{array}{l}\text { Process Mining by Measuring } \\
\text { Process Block Similarity }\end{array}$ & $\begin{array}{l}\text { J. Bae, J. Caverlee, L. } \\
\text { Liu and H. Yan }\end{array}$ & $\begin{array}{l}\text { Workshop on Business Process } \\
\text { Intelligence - Business Process } \\
\text { Management Conference, } 2006\end{array}$ \\
\hline P68 & $\begin{array}{l}\text { Questionnaire-based Variability } \\
\text { Modeling for System } \\
\text { Configuration }\end{array}$ & $\begin{array}{l}\text { M. La Rosa, W. M. } \\
\text { P. van der Aalst, M. } \\
\text { Dumas and A. H. M. } \\
\text { ter Hofstede }\end{array}$ & $\begin{array}{l}\text { Information and System Modeling, } \\
2009\end{array}$ \\
\hline P69 & $\begin{array}{l}\text { Reuse-Oriented Business Process } \\
\text { Modelling Based on a } \\
\text { Hierarchical Structure }\end{array}$ & W. Derguech, S. Bhiri & $\begin{array}{l}\text { Workshop on Reuse in Business } \\
\text { Process Management - Business } \\
\text { Process Management Conference, } \\
2010\end{array}$ \\
\hline P70 & $\begin{array}{l}\text { Similarity of Business Process } \\
\text { Models: Metrics and Evaluation }\end{array}$ & $\begin{array}{l}\text { R. Dijkman, M. } \\
\text { Dumas, B. Van } \\
\text { Dongen, R. Krik and J. } \\
\text { Mendling }\end{array}$ & Information Systems, 2011 \\
\hline P71 & $\begin{array}{l}\text { Similarity Search of Business } \\
\text { Process Models }\end{array}$ & $\begin{array}{l}\text { M. Dumas, L. Garca- } \\
\text { bauelos, R. Dijkman } \\
\text { R. Krik and J. } \\
\text { Mendling }\end{array}$ & $\begin{array}{l}\text { IEEE Data Engineering Bulletin, } \\
2009\end{array}$ \\
\hline P72 & $\begin{array}{l}\text { Structural and Behavioural } \\
\text { Commonalities of Process } \\
\text { Variants }\end{array}$ & $\begin{array}{l}\text { M. Weidlich, M. } \\
\text { Weske, R. Krik and } \\
\text { J. Mendling }\end{array}$ & $\begin{array}{l}\text { Zentral-europischer Workshop ber } \\
\text { Services und ihre Komposition, } \\
2010\end{array}$ \\
\hline P73 & $\begin{array}{l}\text { Support for Business Process } \\
\text { Flexibility in Service } \\
\text { Compositions: An Evaluative } \\
\text { Survey }\end{array}$ & $\begin{array}{l}\text { M. Kapuruge, J. Han } \\
\text { and A. Colman J. } \\
\text { Mendling }\end{array}$ & $\begin{array}{l}\text { Australian Software Engineering } \\
\text { Conference, } 2010\end{array}$ \\
\hline P74 & $\begin{array}{l}\text { Supporting Planned and Ad-Hoc } \\
\text { Changes of Business Processes }\end{array}$ & P. Rittgen & $\begin{array}{l}\text { Workshop on Business Process } \\
\text { Modelling, Development, and } \\
\text { Support - Int'l Conference on } \\
\text { Advanced Information Systems } \\
\text { Engineering, 2006 }\end{array}$ \\
\hline P75 & $\begin{array}{l}\text { Taxonomy of Flexibility in } \\
\text { Business Processes }\end{array}$ & $\begin{array}{l}\text { G. Regev, P. Soffer } \\
\text { and R. Schmid }\end{array}$ & $\begin{array}{l}\text { Workshop on Business Process } \\
\text { Modelling, Development, and } \\
\text { Support - Int'l Conference on } \\
\text { Advanced Information Systems } \\
\text { Engineering, 2006 }\end{array}$ \\
\hline P76 & $\begin{array}{l}\text { Towards a Classification and } \\
\text { Lifecycle of Business Process } \\
\text { Change }\end{array}$ & $\begin{array}{l}\text { K. Ploesser, J. Recker } \\
\text { and M. Rosemann }\end{array}$ & $\begin{array}{l}\text { Workshop on Business Process } \\
\text { Modeling, Development and } \\
\text { Support - Conference on Advanced } \\
\text { Information Systems Engineering, } \\
2008\end{array}$ \\
\hline P77 & $\begin{array}{l}\text { Towards Adaptability and Control } \\
\text { for Knowledge-Intensive Business } \\
\text { Processes: Declarative } \\
\text { Configurable Process }\end{array}$ & $\begin{array}{l}\text { I. Rychkova and S. } \\
\text { Nurcan }\end{array}$ & $\begin{array}{l}\text { Hawaii Int'1 Conference on System } \\
\text { Sciences, } 2011\end{array}$ \\
\hline
\end{tabular}


International Journal of Computer Science \& Information Technology (IJCSIT) Vol 5, No 1, February 2013

\begin{tabular}{|l|l|l|l|}
\hline & Specifications & \\
\hline P78 & $\begin{array}{l}\text { Towards E-government by } \\
\text { Business Process Change - A } \\
\text { Methodology for Public Sector }\end{array}$ & $\begin{array}{l}\text { M. I. Stemberger and } \\
\text { J. Jaklic }\end{array}$ & $\begin{array}{l}\text { Int'1 Journal of Information } \\
\text { Management, 2007 }\end{array}$ \\
\hline P79 & $\begin{array}{l}\text { Validation of Families of Business } \\
\text { Processes }\end{array}$ & $\begin{array}{l}\text { G. Grner, C. Wende, } \\
\text { M. Boskovic, F. S. } \\
\text { Parreiras, T. Walter, } \\
\text { F. Heidenreich, D. } \\
\text { Gasevic and S. Staab }\end{array}$ & $\begin{array}{l}\text { Int'l Conference on Advanced } \\
\text { Information Systems Engineering, } \\
2011\end{array}$ \\
\hline P80 & $\begin{array}{l}\text { Fariability Mechanisms for } \\
\text { Process Models } \\
\text { Schnieders, J. Weiland } \\
\text { and M. Weske }\end{array}$ & $\begin{array}{l}\text { PESOA (Process Family } \\
\text { Engineering in Service- Oriented } \\
\text { Applications) - Report TR, 2005 }\end{array}$ \\
\hline
\end{tabular}

\section{AUTHORS}

George Valença received his master's degree in Computer Science in 2012 from the Federal University of Pernambuco (UFPE)/Brazil, addressing business process variability topic. He is currently a PhD student at UFPE, studying Software Ecosystems field. He also has experience in Business Process Management, Requirements Engineering and Software Quality topics.

Carina Alves is adjunct professor of the Informatis Center (CIn) of UFPE. She received the $\mathrm{PhD}$ degree in Computer Science in 2005 from the University College London/UK. She is currently head of the Computer Systems Department at CIn/UFPE. She studies the fields of Requirements Engineering, Business Process Management and Software Ecosystems.

Vander Alves is adjunct professor of the Computer Science Department of the University of Brasilia/Brazil. He received his PhD degree in Computer Science in 2007 at UFPE, with postdoctoral research at Lancaster University/UK in 2008 and at Fraunhofer Institute/Germany in 2009. He has experience in Software Product Line, Formal Methods and Ambient Assisted Living topics.

Nan Niu is assistant professor of the Department of Computer Science and Engineering of the Mississippi State University/USA. He received his $\mathrm{PhD}$ degree in Computer Science in 2009 at University of Toronto/Canada. He investigates the fields of Requirements Engineering, Program Comprehension and Software Reuse.
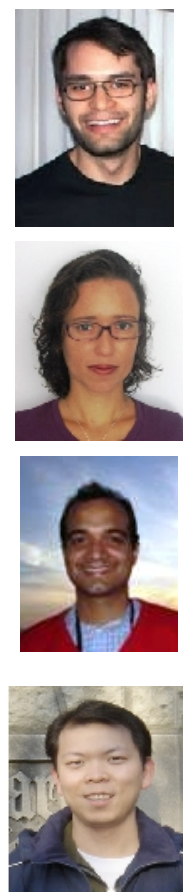